\title{
The Utmost Good Faith in Maritime Insurance: The Nature
}

\author{
Mingting Zhu1,2 \\ ${ }^{1}$ Anhui University of Finance and Economics, Bengbu, China \\ ${ }^{2}$ University College Cork, Cork, Ireland \\ Email:635623536@qq.com
}

How to cite this paper: Zhu, M. T. (2020). The Utmost Good Faith in Maritime Insurance: The Nature. Beijing Law Review, 11, 99-107.

https://doi.org/10.4236/blr.2020.111006

Received: December 23, 2019

Accepted: January 12, 2020

Published: January 15, 2020

Copyright (c) 2020 by author(s) and Scientific Research Publishing Inc. This work is licensed under the Creative Commons Attribution International License (CC BY 4.0).

http://creativecommons.org/licenses/by/4.0/

\begin{abstract}
The Marine Insurance Act 2015 (UK) marked the start of a contemporary period for insurance law because the Act improved the regime for the duty of good faith by transitioning to the duty of fair presentation from traditional doctrines of utmost good faith in the Marine Insurance Act 1906 in the UK. While the obligation of utmost good faith made up the firm cornerstone of insurance law in the past, it has not been an extensive and all-encompassing duty because the nature of uberrimae fidei in insurance contracts has already changed lately. This essay introduces briefly the evolution of uberrimae fidei in marine insurance law and analyses the nature and its dilemma. By comparing the relationship between good faith and the utmost good faith, upon further analysis, the reason why the obligation needs current reform is the downturn of international trade from the macro-level perspective. Moreover, from the micro-level perspective, legal requirements between the subjective state of the insured and the duty of the "fair presentation" are radically different. All in all, though the utmost good faith laid a solid foundation on insurance law, the "fair presentation" in the 2015 Act is more obviously applicable to counterpoise the benefits of the insurer and the insured, which is regarded as insurance relationships' fresh core. Therefore, nowadays this reform is a success on a fair and reasonable legal basis, and it reduces insurance obligations of the insured traditionally to boost the prosperity of the marine insurance business currently.
\end{abstract}

\section{Keywords}

Uberrimae Fidei, Maritime Insurance, Nature, Reason

\section{Introduction}

\subsection{The Definition of Uberrimae Fidei}

Old theory to uberrimae fidei originated in the early stages of marine insurance 
and roughly translated from Latin as "of the utmost good faith" in brief: all parties to marine insurance contracts have mutual responsibilities and insist on their duties in accordance with the highest standards of good faith based on ethics and efficiency. In addition to its essence of insurance contracts, the obligation of utmost good faith also stems from insurance relationships' nature: the insured is regarded to be morally obligated to disclose all the information materials that the insurer is required to bear. It is also economically inevitable because the insurer had no reasonable means to effectively acquire information without modern transportation or ubiquitous digital-transmission.

\subsection{The Brief Evolution of Uberrimae Fidei in Marine Insurance Law}

Uberrimae fidei was historically dealt with insurance contract according to the British case of Carter v. Boehm in 1766, which created a convention that the insured is forced to disclose "special facts" because these facts were often only known to the insureds and the insurers must implicitly trust the insured's statement in the circumstances of the $18^{\text {th }}$ century world. By doing so, the remedy for the insured to detain these "special facts" is to cancel the insurance policy to promote integrity and prevent any party from hiding knowledge secretly to prevail another party to participate in signed agreements, namely contracts (Elizabeth, 2016). ${ }^{1}$ Lord Mansfield, the Chief Justice of the King's Bench, always was actually considered to be the founder of the English insurance law, especially the obligation of utmost good faith in the context of common law. He had established a clear but harsh platform with the continued influence based on principles of policy (Peter, 2012) $)^{2}$, but one of the tricks that people noticed was, avoiding this policy was limited to situations where hidden information was significant to the insured's underwriting risk. ${ }^{3}$

There was a fervent desire for codification that led to the second key event in the history of insurance law from the UK in the 19th century drew to a close ${ }^{4}$ : the legislation drafted by Sir Mackenzie Chalmers and then became the Marine Insurance Act of 1906 which caused controversy before introduced into Parliament. The bill had few supports and a number of objections, of which probably had two major issues: one is the political issue, which was eventually discussed according to the direction of Lord Loreburn; another is the balance of professional legal views, in particular, they thought English written law would cause rigidity of the law, because it could not be promoted to meet the impartiality of cases and might ignore some significant exceptions or contain ambiguity.

At that time, Chalmers had provided a brief summary of the theory of marine ${ }^{1}$ Elizabeth Germano, "A Law and Economics Analysis of the obligation of utmost good faith (Uberrimae Fidei) in Marine Insurance Law for Protection and Indemnity Clubs” (2016) 47 St. Mary's L.J. 727 at 741.

${ }^{2}$ Peter MacDonald Eggers, "The Past and Future of English Insurance Law: Good Faith and Warranties” (2012) 1 UCLJLJ 211 at 214.

${ }^{3}$ Carter v. Boehm 97 Eng. Rep. 1162 (1766) at 1164-1165.

${ }^{4}$ Peter MacDonald Eggers, “The Past and Future of English Insurance Law: Good Faith and Warranties” (2012) 1 UCLJLJ 211 at 215. 
insurance law (1901) and exposed the abstracts to public scrutiny and received criticisms, because he thought once the principles from the abstract had been amended to satisfy those legitimate criticisms, the provisions of the digest could be transformed into the legislation ${ }^{5}$; but at the same time, Chalmers admitted that some ambiguity could only be eliminated through judicial interpretation. ${ }^{6}$ Although Chalmers stressed that he followed his mentor Lord Herschell to draft the legislation, Chalmers's views still have had a great effect on the interpretation of the 1906 Act and the marine insurance law, as mentioned specifically below, according to Pan Atlantic Insurance Co. Ltd. and Another v. Pine Top Insurance Co. Ltd.

\section{The Nature of the Duty of the Utmost Good Faith}

The concept of good faith in S 17 of the Marine Insurance Act of 1906 was adopted, as said above, in the landmark Carter v Boehm case when Lord Mansfield considered, the policy was void because concealing "special facts" was a fraud. ${ }^{7}$ In terms of S 17 itself and a clear edge note or title "Insurance is uberrimae fidei", people have been questioning whether the obligation should be depicted as "good faith" or "the utmost good faith" 8 and in this way, whether it's practical for parties in contracts. However, it would be seen as a distinction between positions applicable to ordinary contracts; to the contrary, the obligation of the utmost good faith needs an extensive scope, namely that all parties do not make false statements and have full disclosure.

S 18 displays the contractual disclosure duty of the insured and subs (4) of S 18 provides for exceptions to disclosure obligations. ${ }^{9} \mathrm{~S} 19$ stipulates the disclosure duty of the agent (the broker) applicable to the assured when going in or signing an insurance contract and under subs (b), there is an exception: if the assured uses the broker for their insurance, the assured and the broker may be exempt from disclosure. In the case, it is too late for the information to come to the insured and cannot be communicated to the broker. S 20 emphasizes that any statement made by the insured to the insurer must be genuine or accurate. Specifically, it distinguishes between statements of facts before concluding the contract and representations of expectations or beliefs during the negotiations for the contract. ${ }^{10}$

Accordingly, some people think the theory of utmost good faith is not only mainly related to pre-contract stage of an insurance contract, in fact, but also applicable to the post-contract stage until claims are settled. The pre-contract

\footnotetext{
${ }^{5}$ Chalmers, Codification of Mercantile Law. 6th ed. at 11-14.

${ }^{6}$ Ibid 14-17.

${ }^{7}$ Good faith prohibits either party from concealing what he knows in confidence and from inducing the other party to enter into a transaction because he knows nothing about this fact and he believes the opposite.

${ }^{8} \mathrm{~A}$ second Consultation Paper concerned to the post-contractual duties for parties and other matters was issued in December 2011 (Consultation Paper No. 204, para. 10.24.).

${ }^{9}$ There are specified in subs (4) of S 18 exceptions to the duty of disclosure, especially amongst information (c) and (d).

${ }^{10}$ The Marine Insurance Act 2015 (UK), Sect. 20(3).
} 
duty and the post-contract duty in S 17 reflect a mutual nature, but according to Manifest Shipping Co. Ltd. v. Uni-Polaris Ins. Co. Ltd. (The Star Sea) ${ }^{11}$, the range of liabilities and remedies available for breach may differ because of different stages. Though the utmost good faith still alive after the completion of the contract for parties, the scope will change depending on whether the insurer has made a decision in the policy or the insured has decided to claim, especially the stage of the relationship which may also be affected.

In conclusion, the application of the insurer's circumvention of liability and the claims processing procedure stand for a new meaning of good faith, namely, the way in which the insurer handles claims. On this basis, the utmost good faith post-contract obligations continue to exist, but their scope of application is limited. In view of the fact that insurers can take severe remedies for fraudulent claims, the insured's liability should not be extended to include "responsible" claims. However, the remedy to be taken in the event of a breach under the implied conditions theory should be the expected ending of the contract and/or damages. There is no utmost good faith to remedy liability for breach of contract damage - the only remedy is to avoid starting or rescinding the contract so that this inflexibility poses special problems. ${ }^{12}$

\section{The Dilemma of the Nature of the Duty of Utmost Good Faith}

Whether utmost good faith is necessary or has become an anachronistic product of the marine insurance law, there are still disputes, mainly including the following two aspects: the first is that its scope of application, the 1906 Act is compiled in the common law formed on the basis of jurisprudence, the law by had no precedent to expand the scope of this obligation to the conclusion of a contract; the second is that once the insurer rejects to pay the insurance, the obligation of utmost good faith undertaken by the insured will be terminated accordingly. Therefore, both parties have been in a state of "confrontation", and it is unrealistic and unreasonable to require the insured to fully disclose their relevant information to the insurer sincerely in this situation.

It is generally accepted that the obligation of utmost good faith is the product of S 17; while as mentioned above, some scholars point out that this doctrine is the implied clause of the contract. The difference between the two views is the consequences of the violation are different. There is a famous argument from Manifest Shipping Co. Ltd. v. Uni-Polaris Ins. Co. Ltd. (The Star Sea) ${ }^{13}$ to illustrate that the utmost good faith extends to the relevant matters concerning insurance claims after the contract is established. In this case, it is not appropriate to invalidate the declaration contract as a relief measure. If the utmost good faith ${ }^{11}$ Manifest Shipping Co. Ltd. v. Uni-Polaris Ins. Co. Ltd. (The Star Sea) [2001] UKHL 1, [2003] 1 A.C. 469, 508-509.

${ }^{12}$ This is not disproportionate to avoid all or all of the remedies of the contract. ab initio is generally related to S 41 of the 1906 Marine Insurance Act (UK).

${ }^{13}$ Manifest Shipping Co. Ltd. v. Uni-Polaris Ins. Co. Ltd. (The Star Sea) [2001] UKHL 1, [2003] 1 A.C. $469,508-09$. 
is a contractual implied term, damages can be an appropriate remedy. If the utmost good faith is not an implied term of the contract, the declaration of the invalidity of the contract will be the only remedy. This legal consequence is too harsh on the one hand and too loose on the other.

Therefore, it is obvious that if the theory of implied clauses in contracts is finally accepted, the court will directly bypass S 17 of the 1906 Act when dealing with the obligation of good faith after the establishment of insurance contracts, and the obligation of utmost good faith before the establishment of contracts is adjusted by special provisions stipulating the obligation of notification and the obligation of presentation, then S 17 will exist in name only.

The "material circumstance" in S $18^{14}$ and S $20^{15}$ of the Marine Insurance Act 1906 , in fact, have an non-decisive impact on cautious insurers to decide whether to accept risk or collect insurance premiums, especially in Pan Atlantic Insurance Co. Ltd. and Another v. Pine Top Insurance Co. Ltd. ${ }^{16}$ In order to avoid a contract that does not disclose the "material circumstance", insurers must be proved, if they know the undisclosed facts, either completely reject the risk or accuse the increase of the premium.

Although the judge supported the defense of Pine Top, there are two issues that cannot be ignored: one is the meaning of the insurance contract may include the misrepresentation or non-disclosure instead of the obligation of good faith and disclosure, which insurers attempt to interpret policy provisions in an excessively severe method; the other is the enforceability of the post-contractual obligation of good faith depends on technical exclusions to beat or decrease other valid claims filed by the insured. Ironically, it is difficult to divide the burden of proof between insurers and insureds but this good faith insurance policy, which drafted in an unambiguous manner from the British courts, still exists at the present day.

\section{Discussion of Similar Nature in Different Law Systems}

Though in Australian law, the courts generally invoke the enforceability of "negotiate contract by good faith" according to contract law, and are willing to recognize implied terms that both parties should cooperate closely in compliance (Chitty \& Beale, 2012) ${ }^{17}$; however, the Australian Maritime Insurance Act of 1984 was almost a replica of the 1906 Act (UK), and the duty of the utmost good faith in the Act was identical to the English Act. ${ }^{18}$

While the Marine Insurance Act 2015 (UK) abolished the doctrine of utmost good faith from the 1906 Act (UK) and it didn't happen overnight. The effects of ${ }^{14} \mathrm{~S} 18$ of the 1906 Act provides: "(2) Every circumstance is material which would influence the judgment of a prudent insurer in fixing the premium, or determining whether he will take the risk". ${ }^{15} \mathrm{~S} 20$ of the 1906 Act provides: "(2) A representation is material which would influence the judgment of a prudent insurer in fixing the premium, or determining whether he will take the risk". ${ }^{16}$ Pan Atlantic Insurance Co. Ltd. and Another v. Pine Top Insurance Co. Ltd. [1994] 2 All ER 581.

${ }^{17}$ J. Chitty \& H. G Beale, Chitty on Contracts, 31 st ed. (London: Sweet \& Maxwell, 2012) at para. 001-041.

${ }^{18}$ Marine Insurance Act 1984 of Australia, Part II-The duty of the utmost good faith. 
the new regulations might take a long time to appear in court, so the British industry got enough notices to get used to it, around the 18-month grace period before it came into effect. The 2015 Act had got rid of all the terrible outcome of the violation of utmost good faith and changed the doctrine into a fresh system called "fair presentation". ${ }^{19}$ It is more fair and stricter than the violation of the traditional doctrine because the insured needs to disclose "every material circumstance" to the insurer. It is first arising from the case of Garnat Trading \& Shipping (Singapore) Pte Ltd. v Baominh Insurance Corp. ${ }^{20}$, the insurer does not take the initiative to ask the facts from S 18(3), the insurer cannot claim the non-disclosure obligation of these facts. The consequences of the "fair presentation" rely on whether the false statement/concealment is "deliberate or reckless" or "neither deliberate nor reckless" so that the remedies of the "fair presentation" changed because it provides a proportionate answer to solve the issue of material non-disclosure.

Following the passage of the 2015 Act, the most perplexingly reported event was in the United States. The week of February 6 to 12, 2015 produced one of the strangest events in the history of comparative law in less than a week. The United States court of justice solemnly issued a solemn pronouncement that the obligation is "deep-rooted", and since there is no international agreement on the traditional doctrine, it is a matter of grave disagreement with possible consequences that are hard to guess (Attilio, 2017). ${ }^{21}$ The difference between the United Kingdom and the United States in the field of marine insurance law is that the former has amended the theory to counterpoise the interests of the insured and the insurer, so that the two parties in the transaction are in a more fair environment; while the latter still adheres to the strictest theory, and with the reversal of the first circuit court, this trend is more uniform.

In fact, as early as 2015, when the US Federal Court faithfully applied the theory, the state courts have derived different standards for disclosure and misrepresentation in insurance contracts. The theory in state law has also penetrated into the federal maritime law through federal court precedents. In particular, some specific federal circuit courts are reluctant to apply traditional marine insurance principles, and thus the trend of splitting regarding the application of the theory appears in federal courts. The Supreme Court officially accelerated this split in the case of Wilburn Boat Co. v. Fireman's Fund Ins. Co. ${ }^{22}$

There are three approaches avoiding the theory by the court, and the first one depends on whether the state law under its jurisdiction is adopted. When the Fifth Circuit applied the Wilburn Boat Principles to determine that state law should be applied to resolve integrity issues, their disagreements with other fed-

\footnotetext{
${ }^{19}$ The Marine Insurance Act 2015 (UK), Sect. 3(1).

${ }^{20}$ Garnat Trading \& Shipping (Singapore) Pte Ltd. v Baominh Insurance Corp. [2011] 1 Lloyd's Rep 589.

${ }^{21}$ Attilio M. Costabel, "Utmost Good Faith in Marine Insurance: A Message on the State of the Dis-Union" (2017) 48 J. Mar. L. \& Com. 1 at 27.

${ }^{22}$ In the case of 348 U.S. 310 (1955), the Supreme Court ruled that because insurance laws are generally governed by states, federal courts should apply state law in marine insurance contracts when there is no well-entered federal maritime law.
} 
eral courts also led to significant differences in the application of the US Maritime Insurance Law on the theory. The second method applied by the court is to divide the obligations of the marine insurance contract into "maritime obligations" and "non-maritime obligations", while in the latter case the theory is not applied, for example in the case of In re Balfour Maclaine Int'l Ltd. ${ }^{23}$ The third way is for the court to permit parties to the maritime contract to get rid of the application of the disclosure obligation rules, as in the light of Kling v. Allstate Insurance $\mathrm{Co}^{24}$

These above approaches to avoiding the theory of utmost good faith, despite criticisms that have led to great uncertainty in the application of US marine insurance laws, have disrupted the coordination of tradition and the necessary Anglo-American law; on the other hand, in practice, the supported voice regarding reform is constant, so there are not many states in the United States that still adhere to the theory in marine insurance, and treat them differently from non-marine insurance. ${ }^{25}$

\section{The Reason of the Current Reform Regarding the Duty of Utmost Good Faith}

\subsection{The Reason of Macro Level}

In the $18^{\text {th }}$ century, since the ship was made of wooden shells, the marine insurance industry was an unsafe childish industry. The risk of the insurer was unimaginable and the insurer was completely in a weak position, so the subject matter of insurance is always under the control of the insured. The specific facts of evaluating the risk are mostly known only to the insured so the insurer can only rely on the insured's notice and statement. The asymmetry of this information made the marine insurance legislation at that time require the insured to assume heavier duties and responsibilities. In order to protect the interests of the disadvantaged parties, the law starts from the counterpoise of interests, and the insured informs the insured of the stated obligation. If the insurer violates these obligations before entering into the insurance contract or negotiating the insurance contract, the contract can be invalidated.

In the $20^{\text {th }}$ century, with the rapid development of economic and technological conditions, the maritime risks of the insurance shipping industry have been greatly reduced, and the status of insurers has changed from weak to strong. The maritime risks faced by the insurer due to the insured's failure to inform or misrepresentation are also reduced accordingly. In addition, the insurer's bargaining power in the insurance market continues to increase, and in many cases, there are some insurers using this system to breach the insurance. Under this circumstance, the status of the insured and the insurer has been reversed, and

${ }^{23} 873$ F. Supp. 862 (S.D.N.Y. 1995).

${ }^{24} 906$ F.2d 1537, (11th Cir. 1990).

${ }^{25}$ Only California, Florida, and New York. See Certain Underwriters at Lloyd's v. Montford 52 F. 3d 219 (9th Cir. 1995); Royal Ins. Co. of Am. v. Fleming. (M.D. Fla. 1985); Albany Ins. Co. v. Wisniewski, 579 F. Supp. 1004. (D.R.I. 1984). 
the insured has been in an unfavorable position. The counterpoise of the actual interests between the insurer and the insured has been broken since the 19th century. It will also lead to institutional reform.

Since the global financial crisis in 2008 affected various industries, it was the downturn of international trade, and the shipping industry was particularly affected as an important part of international trade. The trade industry suffered because exports were largely blocked and a large number of ships were anchored at the port. In this circumstance, if the owner or the owner of the insurance contract suffered a huge loss, they are also subject to a heaviest obligation of utmost good faith and pay for it due to a fact that only has not disclosed, which does not facilitate the transaction with the maritime contract law, while the original intention of the legislation was contrary. The end result is that the shipping industry has not been developed, and the insurance industry as its service industry has not developed.

\subsection{The Reason of Micro Level}

In the practice of maritime insurance, the theory of utmost good faith was mainly to counterpoise the benefits of the insurers and the insureds in the initial stage of establishment. From the current situation, this principle has been transformed into both the parties to the insurance contract that applies to the insurance contract, with a greater focus on balancing the interests of insurers and insureds. Among them, S 2 to 8 of the 2015 Act have a new definition of the obligation to inform of the insured in the marine insurance contract, and the obligation is named as the duty to make a fair presentation.

The new law divides the subjective state of the insured against the duty of fair presentation into two categories: deliberate or reckless, neither intentional nor rash. When the insured is in the former state and violates the duty of fair presentation, the insurer has the right to terminate the contract, refuse to compensate for the loss and have the right to refuse to return the premium paid by the insured; and when the insured is in the latter state, in accordance with the principle of proportionality, three situations may arise ${ }^{26}$ when it is assumed that it has fulfilled its duty of fair presentation.

\section{Conclusion}

Because of the above theory, in fact, the insured's obligation to inform is changed from active and unlimited inform; to inquiry and limited notice ${ }^{27}$. In the determination of the break of the theory, the causation is generally emphasized, only when the insured has intent or gross negligence, the insurer can state the contract of no avail; the traditional view argues that regardless of causality,

\footnotetext{
${ }^{26}$ As note 23 states.

${ }^{27}$ The 2015 Act has re-reformed the voluntary notification obligation model, transforming the purely insured's unilateral notification obligation into the circumstance that the insured's initiative informs the insured mainly, with the supplement of the insurer's inquiry as an aid. A benign development under the premise of fully recognizing the "two-way" requirement of the utmost good faith is a new legislative model worthy of admiration.
} 
when the insured breaches the disclosure obligation, the insurer can call off the contract regardless of subjective faults. However, the good faith standards of insurance contracts under English law exceed the standards of general contracts and also exceed the standards of civil law insurance contracts; for example, the contracting party must think over the interests of the other party in the contracting process and proactively tell relevant parties to vital information about the subject.

Accordingly, though the obligation of utmost good faith made up the firm cornerstone of insurance law in the past, it has not been an extensive and all-encompassing duty because the nature of uberrimae fidei in insurance contracts has already changed lately. As the pre-contractual information disclosure mechanism, from the view of practical operation of the insurance market, the "fair presentation" in the 2015 Act is more obviously applicable to counterpoise the benefits of the insurer and the insured and there are very few prominent phenomena of "information dumping" or "abuse of contract status by insurers". Therefore, nowadays this reform is a success on a fair and reasonable legal basis, and it reduces insurance obligations of the insured traditionally to boost the prosperity of the marine insurance business currently.

\section{Conflicts of Interest}

The author declares no conflicts of interest regarding the publication of this paper.

\section{References}

Attilio, M. C. (2017). Utmost Good Faith in Marine Insurance: A Message on the State of the Dis-Union. Journal of Maritime Law \& Commerce, 48, 1-34.

Chitty, J., \& Beale, H. G. (2012). Chitty on Contracts (31st ed., pp. 1-41). London: Sweet \& Maxwell.

Elizabeth, G. (2016). A Law and Economics Analysis of the Obligation of Utmost Good Faith (Uberrimae Fidei) in Marine Insurance Law for Protection and Indemnity Clubs. St. Mary's Law Journal, 47, 727-820.

Peter, M. E. (2012). The Past and Future of English Insurance Law: Good Faith and Warranties. UCL Journal of Law and Jurisprudence, 1, 211-244. 